\title{
In Nobody's Name: A Checks and Balances Approach to International Judicial Independence
}

\author{
Aida Torres Pérez"
}

\section{Introduction}

By sharply posing the question "In whose name do or should international courts decide?" 1 , Armin von Bogdandy and Ingo Venzke have singled out one of the most pressing challenges in current debates regarding international courts (ICs): the source of their legitimacy. ${ }^{2}$ The proposed answer -the peoples and citizens- puts democratic legitimacy at the center of the inquiry at a time in which there is an increasing concern accompanying the current rise in power and number of ICs.

At the domestic level, state courts can claim to speak in the name of the people to the extent that their authority derives from the constitution, which encapsulates the will of the people as the constituent power. Also, domestic courts are bound to apply the law, as the expression of the will of majority in parliament. Their democratic legitimacy indirectly derives from the application of the law, and only the law, to the resolution of cases brought before them, with exclusion of influences or pressures from others actors, or their own preferences. Indeed, the main objective served by the principle of judicial independence is securing the rule of law.

* Professor of Constitutional Law, Pompeu Fabra University (Barcelona). I would like to thank Professor von Bogdandy for the ongoing discussion about this topic and for helping me to refine my own ideas. The manuscript was submitted in June 2017.

1 Von Bogdandy, A. and Venzke, I. (2014), In Whose Name? A Public Law Theory of International Adjudication. Oxford: Oxford University Press, 5.

2 Follesdal, A. (2013), "The Legitimacy Deficits of the Human Rights Judiciary: Elements and Implications of a Normative Theory", Theoretical Inquiries in Law 14(2), 339-360. 
Still, the fact that domestic courts can invoke the people as the source of their authority does not conceal at least two important reasons for concern over the democratic character of the judiciary. ${ }^{3}$ Let us begin with judicial discretion. Montesquieu's syllogism that limited the role of the judge to "no more than the mouth that pronounces the words of the law" has long been gone. ${ }^{4}$ No one argues that the law is completely determinate or that interpretation does not leave any room for discretion; and there is thus a risk that judges read their own values into the law. The second concern involves judicial law-making. It is possible for judges to contribute to the creation of norms through adjudication. ${ }^{5}$ Moreover, courts are often vested with the power to review and set aside or annul legislation outright. The so-called "counter- majoritarian difficulty" "refers to this capacity to control or even make law. In order to confront this democratic concern, a myriad of interpretive, procedural, or institutional theories have been put forward to justify and constrain the power of courts. ${ }^{7}$

When von Bogdandy and Venzke claim that ICs make their decisions "in the name of the peoples and the citizens," this dual formula reveals the difficulty of identifying the democratic source of authority for ICs. "Peoples" refers to the states in their democratic dimension, and "citizens" to individuals from a transnational or cosmopolitan perspective. ${ }^{8}$ In addition to the inner tension between the two sources, the hurdles of a transnational or cosmopolitan citizenship reflect the lack of a global political community or a global legislator, as well as the democratic deficit of international governance more broadly. In this vein, Besson argued that in order to confront the democratic legitimacy of ICs, and in the absence of

3 Besson, S. (2014), "Getting over the Amour Impossible between International Law and Adjudication" In: C.P.R. Romano, K.J. Alter and Y. Shany (eds), The Oxford Handbook of International Adjudication. Oxford: Oxford University Press, 413-433.

4 Pasquino, P. (2003), "Prolegomena to a Theory of Judicial Power: The Concept of Judicial Independence in Theory and History", The Law and Practice of International Courts and Tribunals 2(1), 11-26, 18.

5 Von Bogdandy and Venzke, supra note 1, 12-14; Besson, supra note 3, 420-426.

6 Bickel, A.M. (1986), The Least Dangerous Branch: The Supreme Court at the Bar of Politics. New Haven: Yale University Press.

7 Among many others, Ely, J.H. (1980), Democracy and Distrust: A Theory of Judicial Review. Cambridge: Harvard University Press; Ackerman, B. (1991), We The People: Foundations. Cambridge: Harvard University Press; Friedman, B. (2009), The Will of the People. New York: Farrar, Straus and Giroux; Ferreres Comella, V. (1997), Justicia Constitucional y Democracia. Madrid: Centro de Estudios Políticos y Constitucionales.

8 Von Bogdandy and Venzke, supra note 1, 209-214. 
an international legislature representing the international community, the only way forward is greater institutionalization of ICs at the international level. ${ }^{9}$

Given the current structure and limits of international law, instead of expecting ICs to speak in the name of all political communities and citizens, this paper will contend that ICs should speak in nobody's name and will shift the focus to judicial independence as a necessary (but not sufficient) condition for the legitimacy of international adjudication. ${ }^{10}$ Adjudication consists in applying the law to specific disputes brought before the court through a binding decision reached in accordance with the corresponding procedural rules. ${ }^{11}$ In doing so, judges should not act on the behalf or speak in the name of any specific actor. Precisely, judicial independence is at the core of what defines any court, including ICs. ${ }^{12}$

This approach does not require surrendering to formalism, since no one disputes that ICs are often presented with cases that leave room for discretion in identifying and interpreting the law, or that the functions of ICs are no longer limited to dispute- resolution, but also include law-making and monitoring state action. ${ }^{13}$ Thus, just as any authority that exercises public power, ICs must be constrained. Judicial independence cannot therefore be understood in terms of the courts' insularity and appropriate constrain-

9 Besson, supra note 3, 430-433: "In the absence of other institutions and especially of a legislature to interact with, and, more generally, of a political community to represent, the judiciary cannot play its interpretive and judicial law-making role. It is neither checked by nor accountable to any institution or community. [...] It is important, as a result, to explore ways of developing an international institutional order besides courts. [...] It requires building a set of institutions outside courts but also around and including them, whether at the same level of governance or across levels of governance in connection with domestic courts and institutions."

10 Benvenisti, E. and Downs, G.W. (2011), "Prospects for the Increased Independence of International Tribunals", German Law Journal 12(5), 1057-1082, 1058.

11 Besson, supra note 3, 417.

12 Romano, C.P.R., Alter, K.J. and Shany, Y. (2014), "Mapping International Adjudicative Bodies, the Issues, and Players" In: Romano, Alter and Shany, supra note 3, 3-26; Jouannet, E. (2010), "Actualité des Questions d'Indépendance et d'Impartialité des JurisdictionsInternationales:LaConsolidationd'unTiersPouvoirInternational?” In: H. Ruiz Fabri and J.-M. Sorel (eds), Indépendance et Impartialité des Juges Internationaux. Paris: Pedone, 271-302, 271-272.

13 Besson, supra note 3, 419-423, argues that the problems arising from judicial discretion and judicial law- making are magnified in international adjudication due to the limited number of sources of international law; the indeterminate nature of certain sources of international law; international legal pluralism; and norms in certain regimes, like international human rights law, that are necessarily abstract. 
ing mechanisms ought to be put in place. The forms of appropriate constraints upon courts might be understood as sources of interdependence that advance their overall legitimacy from the perspective of the checks and balances doctrine.

While the interest and concern regarding international judicial independence is a relatively new phenomenon, the amount of doctrinal analysis of the independence of domestic courts is so abundant that it is tempting to apply a domestic frame of reference to the international sphere. First, I will therefore reflect upon the differences between domestic and international courts in framing a notion of judicial independence adequate for the international sphere. Hereinafter, I will flesh out the notion of judicial interdependence and map the actors that might provide appropriate constraints following a checks and balance approach to the institutional design of ICs.

\section{From the National to the International Judiciary}

Mackenzie and Sands, in their seminal article on the independence of the international judiciary, put forward the following question: "Is it appropriate to treat the independence of the international judiciary as one would that of national judges, or is there something qualitatively different about international law and courts such that different (lesser) standards should apply in the international setting?" ${ }^{14}$ Unfortunately, they left it unanswered.

Given the diverging institutional and political frameworks of domestic and ICs, it is argued that the principles developed at the domestic level cannot be automatically transposed to the international one. ${ }^{15}$ In that regard, how might the differences between domestic and international judiciary affect the way judicial independence is conceived and implemented? ${ }^{16}$

14 Mackenzie, R. and Sands, Ph. (2003), "International Courts and Tribunals and the Independence of the International Judge”, Harvard International Law Journal 44(1), 271-285, 275-276.

15 Crawford, J. and McIntyre, J. (2012), “The Independence and Impartiality of the "International Judiciary" In: S. Shetreet and F. Forsyth (eds), The Culture of Judicial Independence. Leiden: Nijhoff / Brill, 187-214, 191, 205-206, claimed that "the increased intermingling of politics and law, and the fragility of the institutions, might seem to demand more rather than less stringent application of these principles".

16 Mahoney, P. (2008), "The International Judiciary - Independence and Accountability", The Law and Practice of International Courts and Tribunals 7(2), 313-349, 317. 


\section{A. The Pervasiveness of State Consent}

Domestic courts are one of the three branches of power provided for in the constitution. The constitution usually lays down the main principles regarding the structure and composition of the judiciary. Domestic courts enjoy compulsory jurisdiction and coercive powers to enforce their decisions.

To the contrary, the creation of ICs, their jurisdiction, and enforcement of their decisions are conditional upon state consent. ${ }^{17}$ Hence, at least from an institutional perspective, ICs are largely dependent on the states that created them. Several authors have pointed out that dependence and demanded enhanced protection for the judicial independence of ICs. For instance, Mahoney declared that: "This dependence, when coupled with the fact that in the international arena the interplay between law and politics is necessarily more heightened than at national level, makes the position of the international judge more uncomfortable." ${ }^{18}$ As a consequence, his argument goes, "far from pointing to the inapplicability or reduced applicability of the ordinary principles of judicial independence, the international context rather highlights the need to immunize international judges against interference if the notions of justice, fair trial and the rule of law are to be maintained in relation to their work" 19 .

In what follows, we will take a closer look at the argument premised on state consent to argue that the role of state consent is sometimes overstated; that the relevance of state consent varies across courts; and that the dominance of state governments requires, rather than isolation or higher standards of independence, mechanisms to shield ICs from direct governmental pressures or control that reflect the context in which they operate. $^{20}$

17 Crawford and McIntyre, supra note 15, 190-191.

18 Mahoney, supra note 16, 317-318.

19 Ibid.,318.

20 Ibid., 191. 


\section{The origin and the design of ICs}

As the authors of international treaties, the creation and design of ICs is determined by state parties. That state parties be responsible for creating independent ICs poses a puzzling problem from the perspective of state sovereignty has not escaped scholarly attention. ${ }^{21}$

Indeed, Posner and Yoo argued that dependent ICs were more effective than independent ones. ${ }^{22}$ In response, Helfer and Slaughter strived to explain why independent ICs might be in the states' interest. ${ }^{23}$ Relying on political science literature, they held that delegating authority to independent international courts serves the interests of the states to the extent that such delegation enhances the credibility of the states' international commitments. ${ }^{24}$ They argued that states choose independent tribunals over dependent ones when they face multilateral, as opposed to bilateral, cooperation problems, which would be the case, for instance, for treaties that create rights for private parties. ${ }^{25}$ Yet they also pointed out that states face a second level of design decisions where they might set up control mechanisms in order to exert some influence over the courts. ${ }^{26} \mathrm{Helfer}$ and Slaughter formulated a theory of "constrained independence", according to which "states establish independent international tribunals to enhance the credibility of their commitments in specific multilateral settings and then use more fine- grained structural, political, and discursive mechanisms to limit the potential for judicial overreaching" 27 . The authors offered a typology of mechanisms in which they distinguished between formal and political mechanisms for state control (ex ante and ex post), and also diverse constraints coming from the global community, more loosely identified. ${ }^{28}$

21 Moravcsik, A. (2000), “The Origins of Human Rights Regimes: Democratic Delegation in Postwar Europe", International Organization 54(2), 217-252, 219; Helfer, L.R. and Slaughter, A.-M. (2005), "Why States Create International Tribunals: A Response to Professors Posner and Yoo", California Law Review 93(3), 899-956, 932.

22 Posner, E.A. and Yoo, J.C. (2005), "Judicial Independence in International Tribunals", California Law Review 93(1), 1-74.

23 They also challenged the variables and data used by Posner and Yoo.

24 Helfer and Slaughter, supra note 21,33-34.

25 Ibid., 41-42. Moravcsik, supra note 21, 226, in the context of human rights courts, has argued that the reason is to lock in particular preferred domestic policies in the face of future political uncertainty.

26 Helfer and Slaughter, supra note 21, 943.

27 Ibid., 899.

28 Ibid., 945-955. 
They emphasized that this does not mean that the system becomes a "system of judicial dependence in disguise", since those mechanisms might be difficult or costly to exercise for several reasons, and may not be sufficiently effective in practice. ${ }^{29}$

Their work is very valuable since it shows how it can be in the states' interests to create independent ICs, particularly in multilateral regimes, along with mechanisms to ensure a measure of control. This is not to mean that judicial independence is doomed, but must be understood as constrained. At the same time, the authors focus overtly on state governments, and their approach towards a theory of constrained independence is descriptive rather than normative. As it will be argued, some constraining mechanisms might respond to the need to counterbalance the power of ICs using the principle of checks and balances, and allow for a more diverse set of actors that might constrain the action of ICs. Moreover, the effectiveness of those mechanisms in practice might vary over time as the political and institutional context evolves.

\section{Compulsory jurisdiction}

One of the main differences between the national and international judiciary is that while the jurisdiction of domestic courts is compulsory, in the sense that the consent of the defendant is not needed to file a lawsuit, the jurisdiction of ICs is usually conditioned upon state consent. ${ }^{30}$ Nonetheless, as Romano has argued, there has been a paradigm shift from consensual to compulsory jurisdiction. While the principle of state consent still stands, its significance in practice has been reduced: "The expression of consent has become so removed in time and substance from the exercise of jurisdiction that one may question whether consent continues to serve a significant function in the international order." 31

At present, for several ICs, acceptance of the jurisdiction of these courts is a pre- requisite to joining a certain international organization or legal regime, and thus all state parties are subject to the compulsory jurisdiction of the corresponding court, such as the European Court of Human Rights

29 Ibid., 43.

30 Romano, C.P.R. (2007), "The Shift from the Consensual to the Compulsory Paradigm in International Adjudication: Elements for a Theory of Consent", International Law and Politics 39(4), 791-872, 792.

31 Ibid.,795. 
(ECtHR), ${ }^{32}$ the Appellate Body of the World Trade Organization (WTO $\mathrm{AB})$, the Court of Justice of the European Union (CJEU), the Andean Tribunal of Justice (ATJ), and the Caribbean Court of Justice (CCJ), among others. ${ }^{33}$ In other cases, states may decide after becoming parties to an international organization whether they accept the jurisdiction of the corresponding court through an additional protocol or declaration. This is the case, for instance, of the Inter-American Court of Human Rights (IACtHR). Most of the states who ratified the Inter-American Convention on Human Rights (IACHR) accepted the jurisdiction of the Court. ${ }^{34}$ According to Romano, Alter, and Sebregondi, at present, most ICs possess compulsory jurisdiction. ${ }^{35}$ Alter has documented a trend from "old-style" ICs - ICs that lack compulsory jurisdiction where access is limited to the states' parties - to the "new- style" ICs, whose compulsory jurisdiction is far-reaching and where access by non-state actors is possible. ${ }^{36}$

Describing domestic courts, Shapiro argued that the relevance of judicial independence is linked to the shift from arbitration to adjudication as a model for conflict resolution. ${ }^{37}$ In the arbitration model, where jurisdiction is not compulsory and the parties have a choice regarding the arbitrators, institutional independence is not especially pressing from the perspective of legitimacy. However, in multilateral and compulsory jurisdiction courts, structural safeguards to shield the court from external influence become crucial for those subject to its jurisdiction. Similarly, at the international level, the shift from arbitration to adjudication has increased the concern over and demands for the independence of ICs.

32 At first, the jurisdiction of the ECtHR and the authorization to file individual complaints before the Commission were dependent on state consent. Protocol 11, which entered into force in 1998, merged the Commission and the Court, made the jurisdiction of the Court compulsory, and allowed individual complaints.

33 See Alter, K.J. (2014), The New Terrain of International Law: Courts, Politics, Rights. Princeton: Princeton University Press, 84.

34 Out of 25 States that ratified the convention, only four did not accept the jurisdiction of the court: Dominica, Grenada, Jamaica, and Trinidad and Tobago. In addition, Venezuela denounced the Convention in September 2012, which became effective one yearlater.

35 Romano, C.P.R., Alter, K.J. and Sebregondi, F. (2014), "Illustrations: A Reader's Guide" In: Romano, Alter and Shany, supra note 3, 27-39, 32.

36 Alter, supra note 33, 81-85, points out that out of 27 ICs, 21 have mandatory compulsory jurisdiction.

37 Shapiro, M. (1981), Courts. A Comparative and Political Analysis. Chicago: University of Chicago Press. 


\section{Enforcement and compliance}

ICs do not enjoy coercive powers to enforce their decisions and thus compliance depends on state acceptance. ${ }^{38}$ The risk of political backlash, in terms of non- compliance, treaty or legislative override, or other consequences of withdrawal might constrain the decisions of ICs. ${ }^{39}$ One could view the decision of the Grand Chamber of the ECtHR in Lautsi ${ }^{40}$ as a reaction to the opposition by several governments and pressures to reverse the Chamber's decision, which had condemned Italy for the display of crucifixes in public schools.

Nonetheless, sometimes the enforceability difference between the domestic and the international judiciary is also overstated. In order to enforce judgments coercively, domestic courts actually need the collaboration of the executive branch. Shetreet warns against the preemption of the enforcement of judicial decisions by actions of the executive. While the executive has a duty to enforce court decisions, in practice the expectation of compliance is not always fulfilled. Also, this author indicates that the failure to enforce judgments is not always intentional, and that there might be practical or material limits for expeditious enforcement of judgments. ${ }^{41}$

At the international level, despite the fact that IC judgments are binding, ICs do not have the means to coercively compel state authorities to comply or to directly annul legislation or quash national court decisions. Nonetheless, there are more and more mechanisms through which national and international authorities can strengthen the enforcement of IC judgments. At the international level, supervisory bodies might enhance the effectiveness of ICs decisions through diplomatic and other means, such the Committee of Ministers within the Council of Europe. ${ }^{42}$

38 Dzehtsiarou, K. and Coffey, D.K. (2014), "Legitimacy and Independence of International Tribunals: An Analysis of the European Court of Human Rights", Hastings International and Comparative Law Review 37(2), 271-322, 279.

39 Ginsburg, T. (2014), "Political Constraints on International Courts" In: Romano, Alter and Shany, supra note 3, 484-504.

40 Lautsi v. Italy, ECtHR Application No. 30814/06, Judgment of 18 March 2011 (Grand Chamber).

41 Shetreet, S. (2012), "Creating a Culture of Judicial Independence: The Practical Challenge and the Conceptual and Constitutional Infrastructure" In: Shetreet and Forsyth, supra note 15, 15-67, 55-56.

42 Protocol 14 has enhanced the role of the Committee of Ministers in that regard by providing for an action before the ECtHR in case of non-compliance (Article 46 ECHR). 
In addition, enforcement might be secured through the collaboration of various state authorities, such as domestic courts. For instance, the petition for preliminary reference has offered the CJEU a means to ensure the enforcement of its judgments through the action of state courts. National courts have also played relevant roles in other contexts for the enforcement or broader effectiveness of IC rulings, in particular involving the ECtHR and the IACtHR. ${ }^{43}$

In any event, the lack of enforcement powers, the risk of non-compliance, treaty or legislative override, or more broadly, a political backlash, must be taken into account in evaluating ICs' independence. ${ }^{44}$

\section{B. The Isolation and Diversity of ICs}

While the domestic judiciary consists of a system of permanent courts hierarchically organized, the international judiciary tends to be composed of single, specialized courts pertaining to diverse legal systems where jurisdictions might partly overlap. ${ }^{45}$ The absence of a vertically or horizontally integrated judiciary has raised concerns involving the ensuing fragmentation of international law. ${ }^{46}$ In addition, ICs are diverse in terms of structure: some are permanent, others are ad hoc courts; some are inter-state courts and others grant individual standing. Subject-matter (from human rights, economic and political integration, to criminal responsibility $)^{47}$ and functions (from dispute settlement, securing norm-compliance, monitoring the exercise of national and international authority, to law-making) ${ }^{48}$ are also

43 Nollkaemper, A. (2014), "Conversations among Courts: Domestic and International Adjudicators" In: Romano, Alter and Shany, supra note 3, 523-549, 530535 , regarding the role of national courts in implementing ICs' judgments.

44 Carrubba, C.J., Gabel, M. and Hankla, C. (2008), "Judicial Behavior under Political Constraints: Evidence from the European Court of Justice", American Political Science Review 102(4), 435-452; Stone Sweet, A. and Brunell, T.L. (2012), "The European Court of Justice, State Noncompliance, and the Politics of Override", American Political Science Review 106(1), 204-213.

45 Crawford and McIntyre, supra note 15, 190-191.

46 Dupuy, P.-M. and Viñuales, J.E. (2014), "The Challenge of 'Proliferation': An Anatomy of the Debate" In Romano, Alter and Shany, supra note 3, 135-157, 143-149.

47 Romano, Alter and Shany, supra note 12, 12-14.

48 Shany, Y. (2009), "No Longer a Weak Department of Power? Reflections on the Emergence of a New International Judiciary", The European Journal of International Law 20(1), 73-91; von Bogdandy, A. and Venzke, I. (2013), "On the Functions of 
various. All of these elements should be considered in determining the appropriate model of judicial independence to apply.

The purpose here, after all, is not to argue that there exists a single model of judicial independence that will fit all international courts, just as no single model for judicial independence exists at the domestic level. The principle of judicial independence is key in any well-functioning democracy, but the ways in which it is implemented vary across countries and legal cultures. Moreover, the same legal arrangements might operate differently according to the broader socio-legal and political context. ${ }^{49}$

In addition, within the same country, the differing functions performed by certain courts might pose specific challenges for the notion of judicial independence, and, accordingly, diverse institutional arrangements might be put in place. For instance, constitutional courts, where they exist, perform the function of reviewing the constitutionality of legislation, and might also be vested with the function of solving disputes regarding the territorial allocation of powers and protecting fundamental rights. Given the politically charged issues under their jurisdiction, their independence from other political bodies becomes a matter of concern. Often the mechanism for judicial appointment differs from the selection of judges for the ordinary courts. Whereas in civil law countries judges tend to be recruited through merit-based bureaucratic methods, constitutional court judges are appointed by political bodies, such as parliament and government. ${ }^{50}$ While political appointment might undermine the perception of the court's independence, that might be justified in terms of the added accountability that results, in light of the role that constitutional courts play in monitoring legislation. ${ }^{51}$

In any event, Seibert-Fohr, on the basis of the findings of a transnational research project on judicial independence, argues that shared normative denominators regarding judicial independence do exist and identified

International Courts: An Appraisal in Light of the Burgeoning Public Authority", Leiden Journal of International Law (26) 49; von Bogdandy and Venzke, supra note $1,5-17$.

49 Jackson, V.C. (2012), "Judicial Independence: Structure, Context, Attitude” In: A. Seibert-Fohr (ed.), Judicial Independence in Transition. Berlin/Heidelberg: Springer, 19-86, 60.

50 Ibid., 69.

51 Ferreres Comella, supra note 7. 
common concerns and strategies which have become transnational, variations in implementation notwithstanding. ${ }^{52}$

Indeed, at the international level, various nongovernmental and intergovernmental organizations have developed common standards for judicial independence, which have in turn made significant contributions to domestic rules ${ }^{53}$ one example being the Mt. Scopus International Standards on Judicial Independence. ${ }^{54}$ In addition, international human rights organizations have also had an important impact in setting common rules. For instance, within the framework of the Council of Europe, several resolutions and recommendations on judicial independence have been adopted, such as the Magna Charta of Judges, ${ }^{55}$ and there is an advisory body, the Consultative Council of European Judges for issues related to the independence and impartiality of judges, composed exclusively of judges. Furthermore, the ECtHR case law has also been very relevant in setting some minimum requirements and criteria for assessing judicial independence. Although the interest is preserving the right to a fair trial, and a wide margin of discretion for the institutional design of the judiciary is assigned to the states, ECtHR decisions have had an impact upon the institutional dimension of independence. ${ }^{56}$

With regards to the independence of ICs, there has also been an effort to identify common standards, as shown by the Burgh House Principles On The Independence Of The International Judiciary, according to which independence requires that: "The court and the judges shall exercise their functions free from direct or indirect interference or influence by any per-

52 Seibert-Fohr, A. (2012), "Judicial Independence - The Normativity of an Evolving Transnational Principle” In: Seibert-Fohr, supra note 49, 1279-1373, 1279-1281, held that "conceptualizing judicial independence as a functional principle which provides for an obligation of result rather than of means helps to identify it as an international norm which nevertheless gives room for diverse and context-specific implementation".

53 Shetreet, S. (2009), "The Normative Cycle of Shaping Judicial Independence in Domestic and International Law: The Mutual Impact of National and International Jurisprudence and Contemporary Practical and Conceptual Challenges”, Chicago Journal of International Law 10(1) 275-332,275-276.

54 Mt. Scopus Revised International Standards of Judicial Independence, 19 March 2008, approved by the International Association of Judicial Independence and World Peace, available at https://www.jiwp.org/\#!mt-scopus-, approved on $10 \mathrm{March}$ 2008.

55 Recommendation CM Rec (2010) 12.

56 See the latest decisions in Oleksandr Volkov v. Ukraine, ECtHR Application No. 21722/11, Judgment of 9 January 2013; Baka v. Hungary, ECtHR Application No. 20261/12, Judgment of 27 May2014. 
son or entity." ${ }^{57}$ In formulating a normative theory of international judicial independence, and identifying a common core of what judicial independence means and requires, ${ }^{58}$ several considerations must be made for the specificities of the international setting in which ICs operate and the great diversity of ICs that exist, since the optimal degree of independence and the adequate mechanisms must surely vary across courts. Indeed, the comparative analysis of several ICs might offer valuable insight into institutional design and practice.

\section{Separation of Powers}

At the domestic level, the emergence and evolution of the notion of judicial independence occurred hand in hand with the doctrine of separation of powers. ${ }^{59} \mathrm{As}$ has been put, "[t] he culture of judicial independence can only exist in a system which is based on the doctrine of separation of powers" 60 .

The classic formulation of the doctrine of separation of powers corresponds to Montesquieu, who argued for separating the judicial function from the legislative and the executive functions to protect liberty: "There is no liberty, if the judiciary power be not separated from the legislative and executive. Were it joined with the legislative, the life and liberty of the subject would be exposed to arbitrary control; for the judge would then be the legislator. Were it joined to the executive power, the judge might behave with violence and oppression." ${ }^{61}$ Montesquieu further conceived the role of judges as limited to no more than the "mouth that pronounces the words of the law". The tripartite vision of the principle of separation of powers

57 The Burgh House Principles On The Independence Of The International Judiciary were formulated by The Study Group of the International Law Association on the Practice and Procedure of International Courts and Tribunals, in association with the Project on International Courts and Tribunals.

58 Mackenzie and Sands, supra note 14, 285, suggested that despite their diversity, "it is both possible and desirable to identify certain common core guidelines for judicial independence applicable to all international judges, regardless of the tribunal on which they sit".

59 Pasquino, supra note 4, 14-15; Zimmermann, D. (2014), The Independence of International Courts. Baden-Baden: Nomos, 55.

60 Shetreet supra note 41, 19.

61 Montesquieu, The Spirit of the Laws. Cambridge: Cambridge University Press, 157. 
still persists, although it is no longer understood as a pure model of separation (if it truly ever was). ${ }^{62}$

In the American tradition, courts were understood as political actors, involved in lawmaking and in controlling both the legislative and the executive. Thus, their independence has been understood in light of the doctrine of checks and balances ${ }^{63}$ which is addressed to prevent institutions from overstepping their powers. ${ }^{64}$ Ferejohn developed an argument according to which the roots of judicial independence are found in the structural protections afforded by the Constitution, which instituted a complex set of interdependencies among the major departments of government so that "political intrusions on judicial terrain depend on the capacity of politicians to achieve sufficiently high levels of coordination to overcome the checks and balances imposed by the Constitution" 65 .

To what extent might the doctrine of checks and balances be transposed to the international sphere and in particular to the interplay between ICs and other political actors as a normative guiding principle? Clearly, the political and institutional framework in which ICs operate is very different from the domestic framework, and the tripartite separation of powers does not apply. According to constitutional doctrine, all power derives from the people and is allocated among the constituted powers through the constitution. At the international level, sources of power are diverse and the institutions pertaining to overlapping systems are not regulated by a single, ultimate norm. One might by consequence conclude that the principle of separation of powers is not helpful in the international sphere. Nonetheless, the more dynamic and flexible principle of checks and balances should not be excluded as a normative framework for the organization of

62 Carolan, E. (2009), The New Separation of Powers: A Theory of the Modern State. Oxford: Oxford University Press; Möllers, C. (2013), The Three Branches. A Comparative Model of Separation of Powers. Oxford: Oxford University Press; Shetreet, supra note $41,51-52$.

63 Ferejohn, J. (1999), "Independent Judges, Dependent Judiciary: Explaining Judicial Independence", Southern California Law Review 72, 353-384, 362: "the dependence of the judiciary on the political branches is not a constitutional accident. Rather, it fits within the broader federalist scheme of making the major departments of government interdependent rather than establishing a strict separation of powers".

64 Shetreet, supra note 53, 302, argues that the doctrine of checks and balances is "based on the concept that no function of one branch of government should be exercised by another branch and that each branch should function as a check on any improper use of power by the otherbranches".

65 Ferejohn, supra note 63, 356-357. 
power, even if using it would require greater nuance in order to capture the interaction among national, supranational, and international institutions from a multilevel perspective, as the national and the international grow increasingly intertwined. ${ }^{66}$

Although ICs tend to be presented as isolated, the principle of checks and balances places them in a broader institutional setting and enables a critical examination of the constraining mechanisms already in place. In practice, one finds that there are already several mechanisms for legally and politically constraining ICs, which tend to be in the hands of state governments. ${ }^{67}$ At the same time, the constraints placed on the executive by constitutions are virtually absent in the international sphere. ${ }^{68}$

In sum, although the domestic and international judiciaries differ in many respects, sometimes those differences are overstated, ${ }^{69}$ particularly when we focus on multilateral courts with compulsory jurisdiction. Independence is at the core of what defines a court. Nonetheless, the conceptualization of international judicial independence, and particularly its implementation, is made difficult by distinct challenges: the dominance of state governments; the diversity across courts in terms of institutional setting; and the need to reconceptualize the principle of separation of powers at the international level.

\section{From Judicial Independence to Interdependence}

\section{A. Why Interdependence?}

From the outset, one might distinguish between two meanings of judicial independence: independence in the sense of the judge's neutrality vis-à-vis the parties to the case; and in the sense of the independence of the judiciary from the other branches of political authority to perform its func-

66 Torres Pérez, A. (2015), "How can judicial selection secure judicial independence? A checks and balances approach to international courts" In: Bobek, M. (ed.), Selecting Europe's Judges: A Critical Review of the Appointment Procedures to the European Courts. Oxford: Oxford University Press, 181-201, 187.

67 Ginsburg, supra note 39.

68 Bohlander, M. (2012), "Separation of Powers and the International Judiciary - A Vision of Institutional Judicial Independence in International Law" In: Shetreet and Forsyth, supra note 15, 269-280.

69 Ginsburg, supra note 39, 486. 
tion. ${ }^{70}$ The former could be captured under the concept of impartiality, whereas the latter conveys a notion of institutional independence. Both notions are related, but here we will focus on the institutional dimension of judicial independence. In this sense, independence might be understood as the amount of space for adjudication that is free of undue influence from external actors. ${ }^{71}$

To the extent that adjudication is not limited to the automatic application of the law, and that ICs engage in law-making and sometimes enjoy a wide margin of discretion in interpreting the law, their increasing power and influence coupled with the lack of accountability raises serious concerns over their democratic nature. Indeed, absolute independence is neither feasible in practice nor desirable in normative terms. ${ }^{72}$ Judicial independence must therefore be conceived as a relative concept. ${ }^{73}$ The notion of interdependence refers to constraining mechanisms coming from other actors to prevent the court from overstepping its powers. ${ }^{74}$ Interdependence responds to the rationale of the checks and balances principle applied to the action of ICs in their interplay with other authorities.

Drawing the line between proper and improper influences or constraints is thus necessary, albeit difficult, from a normative perspective. As Ferejohn pointed out, "[t]here is a line, sometimes quite fine and hard to discern, that separates appropriate forms of institutional dependence from objectionable interferences with the execution of the judicial power" 75 . Indeed, the mechanisms to check the power of courts might be abused in order to advance self-interest. In the international sphere, those mechanisms and their operation will have to be evaluated in the context of each court. The next section will broadly map the actors that might provide mechanisms of interdependence under the principle of checks and balances.

70 Pasquino, supra note 4, 14-15.

71 Voeten, E. (2013), “International Judicial Independence” In: J.L. Dunoff and M.A. Pollack (eds.), Interdisciplinary Perspectives on International Law and International Relations. Cambridge: Cambridge University Press, 421-444, 421-422.

72 Crawford and McIntyre, supra note 15; Zimmermann, supra note 59.

73 Jouannet, supra note 12, 288-289.

74 Zimmermann, supra note 59, 64: "if [the judiciary] does have some real power, then its independence must be flanked by some degree of interdependence in order to prevent an abuse of isolated independence".

75 Ferejohn, supra note 63, 356. 


\section{B. Interdependence between Whom?}

In the international sphere, courts might be influenced or constrained by a variety of actors. Indeed, the relevant actors and the level of their influence might easily differ across courts. Note that these actors might exert influence or pressure that undermine independence, yet still provide adequate constraints through interdependence.

Several theoretical approaches to courts and international adjudication focus on specific actors and sources of influence. From the perspective of realists and principal-agent theories, the main threat to ICs comes from state governments, since the states create international courts and retain some control through different mechanisms. Neofunctionalist and other sociological approaches emphasize the influence of other actors and the broader social environment and observe how courts might obtain autonomy from governments by seeking the support of other actors, such as domestic courts or civil society organizations. ${ }^{76}$ In this way, diverse sources of interdependence might be established and independence from state governments might actually be gained through increased dependence on other actors.

From this perspective, the relevant actors might be categorized under three main groups: political institutions (domestic and international); courts (domestic and international); and public opinion. Since our approach takes the principle of checks and balances as a guiding principle, public opinion will be set aside. ${ }^{77} \mathrm{~A}$ better analysis of the potential constraints coming from the public opinion, it would seem, would derive from the notion of accountability and the tenets of sociological legitimacy.

\section{State governments}

The main threat to the independence of the international judiciary comes from state governments, since they are responsible for the design of ICs, and they have the power to amend the constitutive rules of ICs. In addition, they might retain control mechanisms, such as those for the selection and reappointment of judges. Furthermore, states might defy the authority of ICs by refusing to comply with IC judgments, voicing discontent with

76 Voeten, supra note 71, 426.

77 Voeten, E. (2013), "Public Opinion and the Legitimacy of International Courts", Theoretical Inquiries in Law 14(2), 411-436. 
specific decisions, or even threatening to withdraw, ${ }^{78}$ as evidenced by the UK's stance towards the ECtHR and the saga of cases about prisoners' voting rights. ${ }^{79}$

Some of the existing control mechanisms might be understood as constraints under a checks and balances approach. If abused, they might pose a threat to independence, but their actual impact in practice might be overemphasized, since some of the mechanisms are costly to activate, require the cooperation of other states, entail reputational costs, or might generate opposition from other states or other international or domestic actors, ${ }^{80}$ and, in the end, their effectiveness depends on contextual factors.

For instance, let us take the example of judicial selection. ${ }^{81}$ This is usually regarded as one of the primary mechanisms through which state governments might influence ICs and rein in their independence, as governments might be tempted to appoint judges who are political allies. In courts with one judge per member state, such as the ECtHR or the CJEU, state governments have more leeway in selecting their candidates, while in courts with fewer judges than states, such as the International Court of Justice (ICJ), the International Criminal Court (ICC), or the IACtHR, state governments need to seek the support of other governments for their candidate to be selected so campaigning and vote-trading have become common practices. ${ }^{82}$ In both, the system of selection is highly politicized and obscure.

Yet, granting the power of judicial selection to state governments might be conceived of as a mechanism to promote interdependence under the principle of checks and balances. To the extent that ICs are granted the

78 Ginsburg, supra note 39.

79 Hirst $\left(n^{\circ} 2\right) v$. the United Kingdom, ECtHR Application No. 74025/01, Judgment of 6 October 2005 (Grand Chamber); Greens and M.T. v. the United Kingdom, ECtHR Applications Nos. 60041/08 and 60054/08, Judgment of 23 November 2010; Firth and Others $v$. the United Kingdom, ECtHR Application Nos. 47784/09, 47806/09, 47812/09, 47818/09, 47829/09, 49001/09, 49007/09, 49018/09, 49033/09 and 49036/09, Judgment of 12 August 2014; McHugh and Others $v$. the United Kingdom, ECtHR Application No. 51987/08, Judgment of 10 February 2015.

80 Helfer and Slaughter, supra note 21, 44.

81 See Torres Pérez, supra note 66.

82 Mackenzie, R. et al. (2010), Selecting International Judges: Principle, Process, and Politics. Oxford: Oxford University Press, 100-128; Faúndez Ledesma, H. (1998), "La independencia e imparcialidad de los miembros de la Comisión y de la Corte: paradojas y desafíos" In: J. Méndez and F. Cox (eds.), El futuro del sistema Interamericano de los Derechos Humanos. San José: Instituto Interamericano de Derechos Humanos, 185-210, 187. 
power to monitor state action (even when resulting from democratic processes), judicial selection by the states to be bound by the ICs' decisions might constitute a warranted check on ICs.

Moreover, the motives for selecting judges vary greatly, and governments look at much more than only talent or political affinity. ${ }^{83}$ Then, once appointed, the capacity of governments to influence judges, ${ }^{84}$ and the capacity of those judges to influence court decisions, both depend on a wide set of factors, including term length, the possibility of re-appointment, the composition of the court, and the collegiate nature of ICs.

To the extent, however, that selection power is concentrated in the hands of state governments, the process risks abuse by governments tempted to nominate loyal judges who will defend their interests. Instead of de-politicizing the selection process, further checks on the action of governments may instead be introduced, such as advisory expert panels that assess the suitability of candidates in terms of their expertise and independence; and/or more transparent procedures both at the national and international level. ${ }^{85}$ Following Voeten, appointment procedures should offer states opportunities "to shape the overall direction of the court, but minimize opportunities for governments to influence judges on individual cases" $" 86$.

\section{International political institutions}

ICs might also be constrained by the political institutions and other bodies of the international organizations in which they operate. The role of specific bodies, such as the Inter-American Commission of Human Rights with regard to the IACtHR, or of international prosecutors in criminal courts should also be considered.

International organizations in which ICs operate commonly include an intergovernmental institution that represents the state parties, such as the Committee of Ministers of the Council of Europe; the General Assembly of the OAS; the Assembly of States Parties for the ICC; or the UN General

83 Voeten, E. (2009), “The Politics of International Judicial Appointments”, Chicago Journal of InternationalLaw 9(2), 387-405, 389, 391-392.

84 Ibid., 403: "Understanding if and how governments influence judicial behaviour requires an understanding both of government motives and of the institutional opportunities to act upon these motives."

85 See Bobek, supra note 66.

86 Voeten, supra note 83, 405. 
Assembly and the Security Council for the ICJ. Intergovernmental bodies offer state governments another avenue to exert influence on ICs in coordination with other states. Indeed, Benvenisti and Downs have indicated that inter-state competition is an important contextual factor that enhances the independence of ICs. ${ }^{87}$ Several forms of constraint might derive from the competences attributed to these bodies in terms of judicial selection (as mentioned above), or the regulation of aspects related to the court's functioning or financing.

For instance, the reform process for the so-called "enhancement" of the Inter- American system ${ }^{88}$ was launched by several states who were unhappy with certain decisions of the Commission. ${ }^{89}$ Proposals for reform included the amendment of several articles of the Statute of the Inter-American Commission. According to Art. 22 of the Statute, the Statute may be amended by the General Assembly. However, a large group of scholars argued against the unilateral amendment of the Commission Statute by the General Assembly. ${ }^{90}$ They held that Art. 22 of the Statute should be read together with Art. 39 of the American Convention, which provides that "[t]he Commission shall prepare its Statute, which it shall submit to the General Assembly for approval" and held that the Statute may not be modified without the proposal for reform being initiated within the Commission itself. ${ }^{91}$ They concluded that "[i]n the case of the Commission, it is clear that its position would be weakened if the reform of the Statute was decided unilaterally by the Member States of the Organization" 92. Eventu-

87 Benvenisti and Downs, supra note 10, 1073, indicate that "[i]nterstate competition occurs at the level of an international organization where state parties compete for power and are divided on policies".

88 Regarding the process of reform, see http://www.reformasidh.org/.

89 Notably Brazil, with regard the interim measures ordered in Belo Monte; and Ecuador and Venezuela, with regard the activities of the Relatoría Especial para la Libertad de Expresión.

90 The legal limits to amendments of the Statute of the Inter-American Commission on Human Rights (IACHR), March 2013.

91 Also, they argued that the current proposals to reform the powers of the Commission could not be achieved through the amendment of the Statute. Instead, the Convention and the Commission's Rules of Procedure would need to be modified.

92 The legal limits to amendments of the Statute of the Inter-American Commission on Human Rights (IACHR), March 2013, para. 67. 
ally, in March 2013, the General Assembly accepted the proposals by the Commission to amend the Rules of Procedure..$^{93}$

Another control mechanism is budgetary, for "every international court is highly dependent on one crucial aspect: the money and resources that it takes for it to function"94. The possibility to tamper with judges' salaries is one way of pressuring a court. The Burgh House Principles point out the relevance of remuneration and conditions of service: "4.1. Judges' essential conditions of service shall be enumerated in legally binding instruments. 4.2. No adverse changes shall be introduced with regard to judges' remuneration and other essential conditions of service during their terms of office. 4.4. Conditions of service should include adequate pension arrangements".

According to Article 50 of the ECHR, the cost of the Court is to be borne by the Council of Europe. At present, the Court does not have a separate budget, but is part of the general budget of the Council of Europe. As such, it is subject to the approval of the Committee of Ministers in the course of their examination of the overall Council budget. ${ }^{95}$

In addition, it is for the Committee of Ministers to set the salary of judges. ${ }^{96}$ Until 2009, the Strasbourg Court was the sole major international court without a pension plan for judges. This situation, however, changed after the Committee of Ministers' Resolution CM/Res(2009)5, which

93 At the same time, the dialogue about the reform was left open in order to reach an agreement with the States that had pushed for deeper reforms, which actually sought to weaken the regional monitoring system. See AG/RES. 1 (XLIV-E/13), Resultado del proceso de reflexión sobre el funcionamiento de la Comisión Interamericana de Derechos Humanos para el fortalecimiento del Sistema Interamericano de Derechos Humanos, 22 March 2013.

94 Terris, D., Romano, C. and Swigart, L. (2007), The International Judge: An Introduction to the Men and Women who Decide the World's Cases. Oxford: Oxford University Press, 160.

95 http://www.echr.coe.int/Pages/home.aspx?p=court/howitworksandc=\#newCompo nent_1346157778000_pointer, accessed 27 December 2017. The Council of Europe is financed by the contributions of the 47 member States, which are fixed according to scales taking into account population and gross national product.

96 Resolution $\mathrm{CM} / \operatorname{Res}(2009) 5$ on the status and conditions of service of judges of the European Court of Human Rights and of the Commissioner for Human Rights. 
granted judges a pension scheme equivalent to that which already existed for staff members of the Council of Europe. ${ }^{97}$

A recent document entitled Reinforcement of the independence of the European Court of Human Rights, issued by the PACE Committee on Legal Affairs and Human Rights, expressed concerns regarding issues such as the social security and pension entitlements and post-retirement status of judges. ${ }^{98}$ Mahoney, former Registrar and current Judge of the ECtHR, expressed concerns regarding the relationship of the political bodies of the Council of Europe and the Court and its operational independence, pointing out "revived attempts by the executive arm of the Council of Europe to assume ultimate responsibility, in place of the Court, for staff appointments and structures, for budgetary preparations, for internal working methods, and so on"99.

Powers attributed to the political bodies of the corresponding international organization might serve as political checks on the IC from an institutional perspective. Some arrangements might be inherently problematic as a matter of design, and others might risk abuse in practice. Whether balance is achieved will be determined by the extent to which those powers are used to encroach upon the court's independence, or to fulfill their role as a potential check on the court.

\section{Domestic courts}

Domestic courts might influence the decision of ICs in several ways and thus contribute to counterbalancing their power. Sociological and neofunctionalist approaches have emphasized the role of domestic courts in the context of enforcement of international judgments and effectiveness more broadly. Alliances with domestic courts might help shield ICs from governmental control, while creating a new source of dependence. In this context, Benvenisti and Downs have emphasized how inter-branch compe-

97 Committee on Legal Affairs and Human Rights, "Need to reinforce the independence of the European Court of Human Rights: Introductory Memorandum", AS/Jur (2013) 34, 12 November 2013, para. 18, available at http://www.assembly.c oe.int/CommitteeDocs/2013/ajdoc34_2013.pdf, accessed 27 December 2017.

98 PACE Committee on Legal Affairs and Human Rights, Reinforcement of the independence of the European Court of Human Rights, 26 May 2014.

99 Quoted in Dzehtsiarou and Coffey, supra note 38. 
tition within a state might contribute to enhance the independence of ICs vis-à- vis state governments. ${ }^{100}$

For the CJEU, the collaboration of state courts through the preliminary reference has been crucial. CJEU decisions are encapsulated in domestic court judgments, which are more difficult for state governments to ignore.

In the context of the ECtHR, a recent case offers a good example of how the collaboration of domestic courts might overcome governmental reluctance. In Del Río Prada v. Spain ${ }^{101}$, the ECtHR condemned Spain for violation of the right to liberty and the right to no punishment without a law subsequent to the retroactive application of a judicial doctrine according to which sentence remissions were no longer to be applied to the maximum term of imprisonment (thirty years), but successively to each of the sentences imposed (the so-called Parot doctrine). Consequently, the ECtHR ordered the release of a convicted terrorist who had fulfilled her prison sentence. Despite the reluctance of the Ministers of Justice and Internal Affairs, ${ }^{102}$ not only did the competent domestic court decide to release the applicant, but also to extend the effects of the judgment to other convicted terrorists in the same circumstances.

In turn, the need for support by domestic courts might also have an effect upon ICs' decisions and promote doctrines of deference or selfrestraint. For example, the CJEU, on occasion, limits itself to issuing guidelines regarding the rights and freedoms or general interest in conflict and defers the application of the proportionality principle to the referring court. ${ }^{103}$

For its part, the ECtHR has developed the well-known and long-disputed margin of appreciation doctrine. The notion of consensus among the states parties is key in the application of the margin of appreciation; but the action of domestic courts is also relevant in determining the scope of the margin left to the states. As such, the ECtHR's review is not as intense when domestic courts have demonstrated that they apply the crite-

100 Benvenisti and Downs, supra note 87, 1075.

101 Del Río Prada v. Spain, ECtHR Application No. 42750/09, Judgment of 21 October 2013 (Grand Chamber).

102 "Estrasburgo revisará la anulación de la doctrina Parot”, El Mundo, 23 October 2012,available at https://www.elmundo.es/elmundo/2012/10/23/espana/1350981 928.html, accessed 27 December 2017; "El Tribunal de Estrasburgo tumba la 'doctrina Parot'”, El País, 21 October 2013, available athttps:/elpais.com/politica/ 2013/10/08/actualidad/1381229761_719630.html, accessed 27 December 2017.

103 For instance, Familiapress, Case 368/95, Judgment of 26 June 1997, ECLI:EU: C:1997:325; Alokpa, Case 86/12, Judgment of 10 October 2013, ECLI:EU: C:2013:645. 
ria previously developed by the Strasbourg case-law regarding the balance between rights in conflict. ${ }^{104}$

\section{International courts}

The forms in which ICs might influence each other should also be taken into consideration. References to the case-law of other ICs might contribute to mutually reinforce their authority vis-à-vis states parties. Also, cross-citation and judicial dialogue might promote coherence and contribute to counteract fragmentation in the international sphere. At the same time, references to other ICs might create forms of epistemic dependence ${ }^{105}$ that could undermine its position vis-à-vis other actors.

In the context of human rights law, cross-citation is quite common, but the patterns vary. For instance, while the IACtHR often quotes the ECtHR, the ECtHR makes a more selective use of the IACtHR case-law, to better ground, for instance, a shift of previous doctrine. ${ }^{106}$ While the reference to the more consolidated Strasbourg case-law might have bolstered the authority of the IACtHR, the perception of a Court too dependent on the European understanding of fundamental rights might prove to be counterproductive.

104 See the von Hannover saga, regarding the conflict between the right to privacy and the freedom of the press: von Hannover $v$. Germany, ECtHR Application No. 59320/00, Judgment of 24 June 2004; von Hannover v. Germany No. 2, Applications Nos. 40660/08 and 60641/08, Judgment of 7 February 2012 (Grand Chamber).

105 Helfer, L.R. and Slaughter, A.-M. (1997), "Toward a Theory of Effective Supranational Adjudication”, Yale Law Journal 107(2), 273-391; Saldías, O. (2012), “Refugiándose enredes epistémicas? El Tribunal de la Comunidad Andina y la independencia judicial” In: M. Hernández Ramos et al. (eds.), Tribunales en Organizaciones de Integración: MERCOSUR, Comunidad Andina y Unión Europea (2012). Cizur Menor: Thomson Reuters Aranzadi, 51-66.

106 Burgorgue-Larsen, L. and Montoya Céspedes, N. (2013), "El diálogo judicial entre la Corte Interamericana de Derechos Humanos y la Corte Europea de Derechos Humanos” In: G. Galindo, R. Urueña and A. Torres Pérez (eds.), Protección Multinivel de Derechos Humanos. Barcelona: Red de Derechos Humanos y Educación Superior, 187-210, available at https://www.upf.edu/dhes-alfa/materia les/docs/PMDH_Manual.pdf, accessed 27 December 2017. 


\section{Concluding remarks}

When domestic courts claim to speak in the name of the people, they employ a rhetorical formula that conveys their submission to the rule of law under the principle of judicial independence. Given the lack of a single global community, ICs cannot invoke the people as the source of their authority and international law does not have the same "democratic pedigree" as national law and cannot provide the same sort of democratic legitimacy, but they are still bound to apply the law under the principle of judicial independence. The differences between domestic and ICs might lead to a different implementation of judicial independence, but independence remains at the core of what defines a court.

The concern for the antidemocratic nature of judicial discretion and law-making that has long existed at the national level is magnified in the international sphere. The adjudicative power wielded by ICs therefore needs to be constrained, although those constraints must also be compatible with the principle of judicial independence. The analysis of ICs from the perspective of checks and balances could be fruitful in this regard.

Indeed, ICs do not operate in isolation, but are embedded in a complex institutional setting. Their adjudicative power is constrained by different national and international actors. They are institutionally dependent on other public authorities for their creation, composition, functioning, and compliance. As argued, existing constraints do not necessarily undermine judicial independence; rather, some might be justified under the checks and balances principle to prevent ICs from overreaching their powers. It is essential to understand how those mechanisms are operationalized in practice. Some, such as non-compliance, might prove costly, and risk generating opposition from other institutions or groups, others, such as treaty amendments, cannot be activated unilaterally, and still others, such as judicial selection, might not be ultimately effective. In turn, the existence of these mechanisms and the capacity to activate them might eventually lead to judicial self-restraint. ${ }^{107}$ Similarly, the predominant role of state governments vis-à-vis ICs might be counterbalanced by other actors. The proper balance to be reached for each IC and whether it is attained must be investigated from a diachronic perspective. In the end, the notion of interdependence captures both the need to ensure decision-making free of undue

107 Ferejohn, J.A. and Kramer, L.D. (2002), "Independent Judges, Dependent Judiciary: Institutionalizing Judicial Restraint”, New York University Law Review 77(4), 962-1039. 
Aida Torres Pérez

external pressures and influences and maintain adequate power constraints according to the principle of checks and balances. 